\title{
Antioxidant and antimicrobial activities of Bauhinia racemosa L. stem bark
}

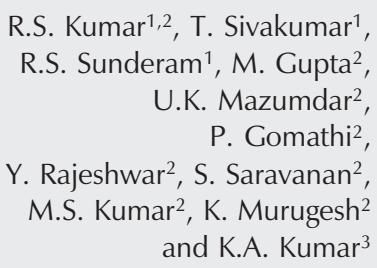

Correspondence

R.S. Kumar

Department of Pharmaceutics and

Pharmacology

J.K.K. Natarajah College of Pharmacy

Namakkal

Tamilnadu

India

E-mail: sambathju2002@yahoo.co.in

......................

Received June 26, 2004

Accepted February 16, 2005

...................

\author{
${ }^{1}$ Department of Pharmaceutics and Pharmacology, \\ J.K.K. Natarajah College of Pharmacy, Namakkal, Tamilnadu, India \\ ${ }^{2}$ Division of Pharmacology and Pharmaceutical Chemistry, \\ Department of Pharmaceutical Technology, Jadavpur University, Kolkata, India \\ ${ }^{3}$ Department of Pharmacology, Sri Ramakrishna Institute of Paramedical Sciences, \\ Coimbatore, Tamilnadu, India
}

\section{Abstract}

The present study was carried out to evaluate the antioxidant and antimicrobial activities of a methanol extract of Bauhinia racemosa (MEBR) (Caesalpiniaceae) stem bark in various systems. 1,1-Diphenyl-2-picryl-hydrazyl (DPPH) radical, superoxide anion radical, nitric oxide radical, and hydroxyl radical scavenging assays were carried out to evaluate the antioxidant potential of the extract. The antioxidant activity of the methanol extract increased in a concentration-dependent manner. About 50, 100, 250, and $500 \mu \mathrm{g}$ MEBR inhibited the peroxidation of a linoleic acid emulsion by $62.43,67.21,71.04$, and $76.83 \%$, respectively. Similarly, the effect of MEBR on reducing power increased in a concentration-dependent manner. In DPPH radical scavenging assays the $\mathrm{IC}_{50}$ value of the extract was $152.29 \mu \mathrm{g} /$ $\mathrm{ml}$. MEBR inhibited the nitric oxide radicals generated from sodium nitroprusside with an $\mathrm{IC}_{50}$ of $78.34 \mu \mathrm{g} / \mathrm{ml}$, as opposed to $20.4 \mu \mathrm{g} / \mathrm{ml}$ for curcumin. Moreover, MEBR scavenged the superoxide generated by the PMS/NADH-NBT system. MEBR also inhibited the hydroxyl radical generated by Fenton's reaction, with an $\mathrm{IC}_{50}$ value of more than $1000 \mu \mathrm{g} / \mathrm{ml}$, as compared to $5 \mu \mathrm{g} / \mathrm{ml}$ for catechin. The amounts of total phenolic compounds were also determined and $64.7 \mu \mathrm{g}$ pyrocatechol phenol equivalents were detected in MEBR $(1 \mathrm{mg})$. The antimicrobial activities of MEBR were determined by disc diffusion with five Grampositive, four Gram-negative and four fungal species. MEBR showed broad-spectrum antimicrobial activity against all tested microorganisms. The results obtained in the present study indicate that MEBR can be a potential source of natural antioxidant and antimicrobial agents.
Key words

- Bauhinia racemosa

- Antioxidant activity

- Lipid peroxidation

- Scavenging superoxide

- DPPH assay

- Antimicrobial activity

\section{Introduction}

Reactive oxygen species (ROS), which include free radicals such as superoxide anion radicals $\left(\mathrm{O}_{2}^{-}\right)$, hydroxyl radicals $\left(\mathrm{OH}^{*}\right)$ and non-free-radical species such as $\mathrm{H}_{2} \mathrm{O}_{2}$ and singlet oxygen $\left({ }^{1} \mathrm{O}_{2}\right)$, are various forms of activated oxygen (1-3). The importance of free radicals and ROS has attracted increasing attention over the past decade (1). These molecules are exacerbating factors in cellular injury and in the aging process (4). ROS have aroused significant interest among scientists. Their broad range of effects on bio- 
logical and medicinal systems has been studied in many experimental investigations (5). In living organisms, various ROS can form in different ways. Normal aerobic respiration stimulates polymorphonuclear leukocytes and macrophages, and peroxisomes appear to be the main endogenous sources of most of the oxidants produced by cells. Exogenous sources of ROS include tobacco smoke, certain pollutants, organic solvents, and pesticides (6-8).

The problem of microbial resistance is growing and the outlook for the use of antimicrobial drugs in the future is still uncertain. Therefore, actions must be taken to reduce this problem, such as controlling the use of antibiotics, carrying out research to better understand the genetic mechanisms of resistance, and continuing investigations aiming at the development of synthetic or natural new drugs. The ultimate goal is to offer appropriate and efficient antimicrobial drugs to the patient.

For a long period of time, plants have been a valuable source of natural products for maintaining human health, especially in the last decade, with more intensive studies devoted to natural therapies. The use of plant compounds for pharmaceutical purposes has gradually increased in India. About $80 \%$ of individuals from developed countries use traditional medicine, which involves compounds derived from medicinal plants. Therefore, such plants should be investigated to better understand their properties, safety and efficiency. The use of plant extracts and phytochemicals, both with known antimicrobial properties, can be of great significance in therapeutic treatments. Hence, studies involving the use of plants as therapeutic agents should be emphasized, especially those related to the control of antibioticresistant microbes.

The plant Bauhinia racemosa Lam. belongs to the Caesalpiniaceae Family. It is popularly known as Sittacha (Tamil) and occurs frequently in India, Ceylon, China, and Timor. The stem bark of the plant is an astringent and is used in the treatment of headache, fever, skin diseases, tumors, blood diseases, dysentery, and diarrhea (9). Chemical constituents such as $\beta$-sitosterol and $\beta$-amyrin (10), probably responsible for the popular use of the plant, were isolated from the stem bark of this plant. Beside these compounds, at least five flavonols (kaempferol and quercetin) and two coumarins (scopoletin and scopolin) were also isolated from the leaves of the plant (11). Stilbene (resveratrol) was isolated from the heartwood of B. racemosa (12). Pharmacological studies of the plant have revealed that the ethanol extract of $B$. racemosa leaves shows analgesic, antipyretic, anti-inflammatory, and antispasmodic activities (13), as well as antimicrobial activity (14). The fresh flower buds of the plant showed antiulcer activity (15). Cytotoxicity against CA-9 KB in cell culture, as well as hypotensive and hypothermic activities have been reported from the hydroalcoholic extract of B. racemosa (16). Previous results from our laboratory have also demonstrated the antioxidant and hepatoprotective effects (17), as well as the antitumor and antioxidant status of B. racemosa against Ehrlich ascites carcinoma in Swiss albino mice (18).

The purpose of the present study was to evaluate the in vitro antioxidant and antimicrobial activities of the methanol extract of B. racemosa Lam. (MEBR).

\section{Material and Methods}

\section{Plant materials and extraction}

B. racemosa Lam. (Family: Caesalpiniaceae) is a small crooked, bushy tree with drooping branches found throughout India up to an altitude of 1,650 $\mathrm{m}$ above sea level. The stem bark was collected in the month of March 2003 from the Kolli Hills, Tamil Nadu, India. The plant material was taxonomically identified by Dr. Ajay Chakrabarti, Botanical Survey of India (B.S.I), Shibpur, Kolkata, India, and a Voucher specimen (No. GMS1) was deposited in the B.S.I. herbarium. 
The dried powder material of the stem bark of $B$. racemos $a$ was extracted with methanol ( $9.25 \%$ yield) in a Soxhlet apparatus. The methanol extract was then distilled, evaporated and vacuum dried. The chemical constituents of the extract were identified by qualitative analysis followed by confirmation by thin layer chromatography. The extract showed a positive Shinoda test for flavonoids, a positive Liebermann-Burchard reaction for steroids, and a positive Noller test for triterpenoids. These results were confirmed by silica gel $\mathrm{G}$ thin layer chromatography using the solvent system benzene-ethyl acetate (1:1). Further separation of the specific phytochemicals is in progress in our laboratory.

\section{Chemicals}

Ammonium thiocyanate was purchased from Merck, Darmstadt, Germany. Ferrous chloride, ferric chloride, 1,1-diphenyl-2-picryl-hydrazyl (DPPH), NADH, EDTA, butylated hydroxy toluene (BHT), butylated hydroxy anisole (BHA), $\alpha$-tocopherol, ascorbic acid, quercetin, catechin, pyrocatechol, curcumin, nitroblue tetrazolium (NBT), thiobarbituric acid, 2-deoxy-2-ribose, trichloroacetic acid, phenazine methosulfate, and potassium ferricyanide were purchased from Sigma, St. Louis, MO, USA. All other unlabeled chemicals and reagents were of analytical grade.

\section{Determination of total antioxidant activity}

The antioxidant activity of MEBR was determined by the thiocyanate method (19). Ten milligrams MEBR was dissolved in 10 $\mathrm{ml}$ water and various MEBR concentrations $(50,100,250$, and $500 \mu \mathrm{g} / \mathrm{ml})$ were added to a linoleic acid emulsion $(2.5 \mathrm{ml}, 40 \mathrm{mM}, \mathrm{pH}$ 7.0) and phosphate buffer $(2 \mathrm{ml}, 40 \mathrm{mM}, \mathrm{pH}$ 7.0). The linoleic acid emulsion was prepared by mixing $0.2804 \mathrm{~g}$ linoleic acid, $0.2804 \mathrm{~g}$ Tween-20 as emulsifier and $50 \mathrm{ml}$
$40 \mathrm{mM}$ potassium phosphate buffer and the mixture was then homogenized. The final volume was adjusted to $5 \mathrm{ml}$ with $40 \mathrm{mM}$ potassium phosphate buffer, $\mathrm{pH}$ 7.0. The mixed samples were then incubated at $37^{\circ} \mathrm{C}$ in a glass flask for $60 \mathrm{~h}$ to accelerate the oxidation process (20). One milliliter of the incubated sample was removed at 12-h intervals and $0.1 \mathrm{ml} 20 \mathrm{mM} \mathrm{FeCl}_{2}$ and $0.1 \mathrm{ml} 30 \%$ ammonium thiocyanate were added. The amount of peroxide was determined by measuring absorbance at $500 \mathrm{~nm}$. $\alpha$-Tocopherol was used as a reference compound. To eliminate the solvent effect, the control sample, which contained the same amount of solvent added to the linoleic acid emulsion in the test sample and reference compound, was used. All data reported are the average of triplicate analyses. Percent inhibition of lipid peroxide generation was measured by comparing the absorbance values of control and test samples.

\section{Reducing power}

The reducing power of MEBR was determined by the method of Oyaizu (21). Ten milligrams of MEBR in $1 \mathrm{ml}$ distilled water was mixed with $2.5 \mathrm{ml} 200 \mu \mathrm{M}$ potassium phosphate buffer, $\mathrm{pH} 6.6$, and $2.5 \mathrm{ml} 1 \%$ potassium ferricyanide $\left[\mathrm{K}_{3} \mathrm{Fe}(\mathrm{CN})_{6}\right]$. The mixture was incubated at $50^{\circ} \mathrm{C}$ for $20 \mathrm{~min}$. A $2.5-\mathrm{ml}$ aliquot of $10 \%$ trichloroacetic acid was added to the mixture, which was then centrifuged at $3000 \mathrm{~g}$ for $10 \mathrm{~min}$. The upper layer of the solution $(2.5 \mathrm{ml})$ was mixed with $2.5 \mathrm{ml}$ distilled water and $0.5 \mathrm{ml} 0.1 \% \mathrm{FeCl}_{3}$ and absorbance was measured at $700 \mathrm{~nm}$. BHT was used as a reference material. All tests were performed in triplicate and the graph was plotted with the average of the three determinations.

\section{Radical scavenging activity of MEBR}

The free radical scavenging activity of MEBR was measured using DPPH by the 
method of Blois (22). A 0.1-mM solution of DPPH in methanol was prepared and $1 \mathrm{ml}$ of this solution was added to $3 \mathrm{ml}$ of various quantities of MEBR $(50,100,150,200$, and $250 \mu \mathrm{g}$ ) and the reference compound. After $30 \mathrm{~min}$, absorbance was measured at 517 nm. BHA was used as a reference material. All tests were performed in triplicate. Percent inhibition was calculated by comparing the absorbance values of control and samples.

\section{Scavenging activity of the nitric oxide radical}

Nitric oxide generated from sodium nitroprusside in aqueous solution at physiological $\mathrm{pH}$ interacts with oxygen to produce nitrite ions, which were measured by the Griess reaction (23). The reaction mixture $(3 \mathrm{ml})$ containing $10 \mathrm{mM}$ sodium nitroprusside in phosphate-buffered saline and MEBR and the reference compound at different concentrations $(10,25,50,75$, and $100 \mu \mathrm{g}$ ) were incubated at $25^{\circ} \mathrm{C}$ for $150 \mathrm{~min}$. A $0.5-\mathrm{ml}$ aliquot of the incubated sample was removed at 30-min intervals and $0.5 \mathrm{ml}$ Griess reagent $(1 \%$ sulfanilamide, $0.1 \%$ naphthylethylene diamine dihydrochloride in $2 \%$ $\mathrm{H}_{3} \mathrm{PO}_{4}$ ) was added. The absorbance of the chromophore formed was measured at 546 $\mathrm{nm}$. All tests were performed in triplicate. Percent inhibition of the nitric oxide generated was measured by comparing the absorbance values of control and test preparations. Curcumin was used as a positive control.

\section{Superoxide anion radical scavenging activity of MEBR}

The superoxide anion scavenging activity of MEBR was determined by the method described by Nishimiki et al. (24), slightly modified. About $1 \mathrm{ml}$ NBT solution containing $156 \mu \mathrm{M}$ NBT dissolved in $1.0 \mathrm{ml} 100$ $\mathrm{mM}$ phosphate buffer, $\mathrm{pH} 7.4,1 \mathrm{ml} \mathrm{NADH}$ solution containing $468 \mu \mathrm{MNADH}$ dissolved in $1 \mathrm{ml} 100 \mathrm{mM}$ phosphate buffer, $\mathrm{pH}$ 7.4, and $0.1 \mathrm{ml}$ of various concentration of MEBR and reference compounds (10, 25, 50, 75, and $100 \mu \mathrm{g}$ ) were mixed and the reaction was started by adding $100 \mu \mathrm{l}$ phenazine methosulfate solution containing $60 \mu \mathrm{M}$ phenazine methosulfate in $100 \mathrm{mM}$ phosphate buffer, $\mathrm{pH}$ 7.4. The reaction mixture was incubated at $25^{\circ} \mathrm{C}$ for $5 \mathrm{~min}$ and absorbance at $560 \mathrm{~nm}$ was measured against control samples. BHT and quercetin were used as reference compounds. All tests were performed in triplicate. Percent inhibition was calculated by comparing the results of control and test samples.

\section{Hydroxyl radical scavenging activity}

Hydroxyl radical scavenging activity was measured by studying the competition between deoxyribose and test compounds (MEBR) for hydroxyl radical generated by the $\mathrm{Fe}^{3+}$-ascorbate-EDTA- $\mathrm{H}_{2} \mathrm{O}_{2}$ system (Fenton reaction) according to the method of Kunchandy and Rao (25). The reaction mixture containing, in a final volume of $1.0 \mathrm{ml}$, $100 \mu 1$ 2-deoxy-2-ribose ( $28 \mathrm{mM}$ in $20 \mathrm{mM}$ $\mathrm{KH}_{2} \mathrm{PO}_{4}-\mathrm{KOH}$ buffer, $\mathrm{pH} 7.4$ ), $500 \mu 1$ of the various concentrations of MEBR and reference compound $(1,100$, and $1000 \mu \mathrm{g})$ in $\mathrm{KH}_{2} \mathrm{PO}_{4}-\mathrm{KOH}$ buffer (20 mM, pH 7.4), 200 $\mu 11.04 \mathrm{mM}$ EDTA and $200 \mu \mathrm{M} \mathrm{FeCl}_{3}(1: 1 \mathrm{v} /$ v), $100 \mu 11.0 \mathrm{mM} \mathrm{H}_{2} \mathrm{O}_{2}$, and $100 \mu 11.0 \mathrm{mM}$ ascorbic acid, was incubated at $37^{\circ} \mathrm{C}$ for $1 \mathrm{~h}$. One milliliter $1 \%$ thiobarbituric acid and 1.0 $\mathrm{ml} \mathrm{2.8 \%} \mathrm{trichloroacetic} \mathrm{acid} \mathrm{were} \mathrm{added} \mathrm{to}$ the test tubes and incubated at $100^{\circ} \mathrm{C}$ for 20 min. After cooling, absorbance was measured at $532 \mathrm{~nm}$ against a control preparation containing deoxyribose and buffer. Catechin was used as a positive control. Reactions were carried out in triplicate. Percent inhibition was determined by comparing the results of the test and control compounds.

\section{Amount of total phenolic compounds}

Total soluble phenolic compounds in the 
MEBR were determined with the FolinCiocalteu reagent according to the method of Slinkard and Singleton (26). A 0.1-ml aliquot of a suspension of $1 \mathrm{mg}$ MEBR in water was totally transferred to a $100-\mathrm{ml}$ Erlenmeyer flask and the final volume was adjusted to $46 \mathrm{ml}$ by the addition of distilled water. Next $1 \mathrm{ml}$ Folin-Ciocalteu reagent was added to this mixture, followed by $3 \mathrm{ml}$ $2 \% \mathrm{Na}_{2} \mathrm{CO}_{3} 3$ min later. Subsequently, the mixture was shaken for $2 \mathrm{~h}$ at room temperature and absorbance measured at $760 \mathrm{~nm}$. All tests were performed in triplicate. The concentration of total phenolic compounds in MEBR was determined as $\mu \mathrm{g}$ pyrocatechol equivalents using the following equation obtained from a standard pyrocatechol graph:

Absorbance $=0.001 \mathrm{x}$ pyrocatechol $(\mu \mathrm{g})$ $+0.0033$

\section{Antimicrobial activity}

Preparation of test microorganisms

Pseudomonas aeruginosa (ATCC 9027, Gram negative), Escherichia coli (ATCC 9837, Gram negative), Salmonella typhi (ATCC 43579, Gram negative), Shigella dysenteriae (ATCC 13313, Gram negative), Vibrio cholerae (ATCC 14033, Gram negative), Staphylococcus aureus (ATCC 6538, Gram positive), Streptococcus pneumoniae (ATCC 49619, Gram positive), Micrococcus luteus (ATCC 10240, Gram positive), and Staphylococcus epidermidis (ATCC 12228 , Gram positive) were used to determine antibacterial activity. Fungal organisms such as Candida albicans (ATCC, 10231), Aspergillus niger (ATCC 16404), Aspergillus flavus (ATCC 9643), and Alternaria solani (ATCC 20476) strains were also employed for the determination of antifungal activity.

Bacteria and fungi were obtained from the stock cultures of the Central Drugs Laboratory, Kolkata (CDL), Indian Institute of
Chemical Biology (IICB), Kolkata, and of the Mycology and Plant Pathology Laboratory, Kolkata, India. The bacterial and fungal stock cultures were maintained on Müller Hinton agar and Sabouraud-dextrose agar slants, respectively, which were stored at $4^{\circ} \mathrm{C}$. Thirteen microorganisms maintained on Nutrient agar base were used to assess the antimicrobial activity of the plant extract. The fungi were maintained on Sabourauddextrose agar, which is often used with antibiotics for the isolation of pathogenic fungi.

\section{Determination of antimicrobial activity}

Agar cultures of the test microorganisms were prepared as described (27). Three to five similar colonies were selected and transferred to $5 \mathrm{ml}$ broth with a loop and the broth cultures were incubated for $24 \mathrm{~h}$ at $37^{\circ} \mathrm{C}$. The MEBR was dissolved in sterile water with a magnetic stirrer. For screening, sterile 6-mm diameter filter paper discs were impregnated with 25-200 $\mu \mathrm{g}$ of the MEBR and placed in Müller Hinton agar. The inoculum for each organism was prepared from broth cultures. The concentration of cultures was to $1 \times 10^{5}$ colony forming units $/ \mathrm{ml}$. The results were recorded by measuring the zones of growth inhibition surrounding the disc. Clear inhibition zones around the discs indicate the presence of antimicrobial activity. All data regarding antimicrobial activity are the average of triplicate analyses. Ofloxacin (5 $\mu \mathrm{g} / \mathrm{disc})$, and the antifungal compound miconazole nitrate ( $40 \mu \mathrm{g} / \mathrm{disc})$ were used as reference standards, as recommended by the National Committee for Clinical Laboratory Standards.

\section{Statistical analysis}

Data are reported as the mean \pm SD of three measurements. Statistical analysis was performed by the Student $t$-test and by ANOVA. $\mathrm{IC}_{50}$ values for all the above experiments were determined by linear regres- 
sion. $\mathrm{P}<0.05$ was regarded as significant.

\section{Results and Discussion}

\section{Antioxidant activity}

In the present study, the antioxidative activity of the MEBR was determined by the ammonium thiocyanate method which measures the peroxide level during the initial stages of lipid oxidation. The antioxidant activity of MEBR might be due to hydroper-

Figure 1. Inhibition (\%) of lipid peroxidation in a linoleic acid emulsion by different doses of the methanol extract of Bauhinia racemosa (MEBR) and by $\alpha$-tocopherol ( $\alpha$-Tph). Data are reported as means \pm SD of three measurements. ${ }^{*} \mathrm{P}<0.05 \mathrm{com}$ pared to control (C; ANOVA followed by the Student $t$-test).
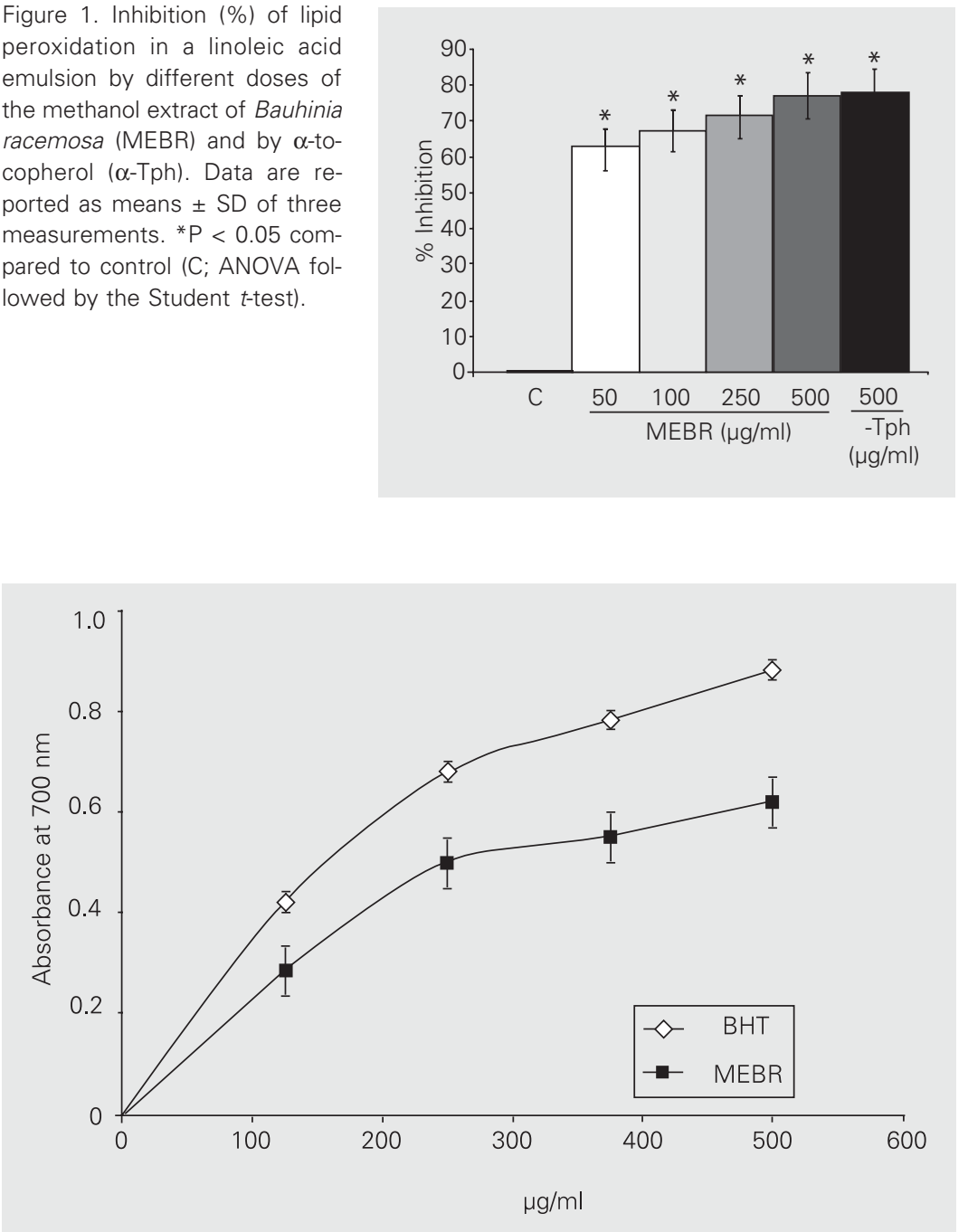

Figure 2. Reducing power of a methanol extract of Bauhinia racemosa (MEBR, squares) and butylated hydroxy toluene (BHT, diamonds). Data are reported as the means \pm SD for three measurements. $\mathrm{P}<0.01$ compared to control $(\%$ inhibition by control $=0 \%$; ANOVA followed by the Student $t$-test). oxides, inactivation of free radicals or complex forming with metal ions, or combinations thereof. This good antioxidant activity of MEBR might be attributed to the presence of phytochemicals such as flavonoids and biflavones (28). Figure 1 illustrates the antioxidative activities of various MEBR concentrations $(50,100,250$, and $500 \mu \mathrm{g} / \mathrm{ml})$, which showed antioxidant activities in a concentration-dependent manner and 62.43, $67.21,71.04$, and $76.83 \%$ inhibition of lipid peroxidation of the linoleic acid system, respectively. MEBR at the concentration of $500 \mu \mathrm{g} / \mathrm{ml}$ showed $76.83 \%$ inhibition, an antioxidant activity approximately equal to that of $500 \mu \mathrm{g} / \mathrm{ml} \alpha$-tocopherol (77.93\%). The $\mathrm{IC}_{50}$ value of MEBR on lipid peroxidation was $38.46 \mu \mathrm{g} / \mathrm{ml}$. The results indicate that the methanol extract of $B$. racemosa significantly $(\mathrm{P}<0.05)$ inhibited linoleic acid peroxidation. The antioxidative activity of the stem of $B$. racemosa may be due to the reduction of hydroperoxides, inactivation of free radicals, chelation of metal ions, or combinations thereof.

\section{Reducing ability}

Antioxidant activity has been reported to be concomitant with the development of reducing power (29). However, this pattern was not observed in the present study. Okuda et al. (30) reported that the reducing power of tannins prevents liver injury by inhibiting the formation of lipid peroxides. The reducing capacity of a compound may serve as a significant indicator of its potential antioxidant activity (31). Figure 2 shows the reducing capacity of MEBR compared with BHT. The reducing capacity of a compound may serve as a significant indicator of its potential antioxidant activity (23). Like antioxidant activity, the reducing power of MEBR increased with increasing amount of sample. All MEBR concentrations showed higher activities than control and these differences were significant $(\mathrm{P}<0.01)$. 


\section{DPPH radical scavenging activity}

The DPPH radical is considered to be a model of lipophilic radical. A chain reaction in lipophilic radicals was initiated by lipid autoxidation. The radical scavenging activity of MEBR was determined from the reduction in absorbance at $517 \mathrm{~nm}$ due to scavenging of stable DPPH free radical. The positive DPPH test suggests that the samples are free radical scavengers. The scavenging effects of MEBR and BHA on the DPPH radical are illustrated and compared in Figure 3A. MEBR had significant scavenging effects on the DPPH radical which increased with increasing concentration in the 50-250 $\mu \mathrm{g} / \mathrm{ml}$ range; the scavenging effect of MEBR was lower than that of BHA. The $\mathrm{IC}_{50}$ value of MEBR in the DPPH radical scavenging assay was $152.29 \mu \mathrm{g} / \mathrm{ml}$, a statistically significant result $(\mathrm{P}<0.05)$.

\section{Nitric oxide radical scavenging activity}

It is well known that nitric oxide has an important role in various types of inflammatory processes. In the present study, the crude leaf extract was checked for its inhibitory effect on nitric oxide production. Figure 3B illustrates the percent inhibition of nitric oxide generation by MEBR. Curcumin was used as a reference compound. The concentration of MEBR needed for 50\% inhibition was $78.34 \mu \mathrm{g} / \mathrm{ml}$, whereas $20.4 \mu \mathrm{g} / \mathrm{ml}$ was needed for an equal weight of curcumin. The results were statistically significant $(\mathrm{P}<0.05)$.

\section{Superoxide anion radical scavenging activity}

Superoxide anions indirectly initiate lipid oxidation as a result of superoxide and hydrogen peroxide, serving as precursors of singlet oxygen and hydroxyl radicals (30). Robak and Glyglewski (32) reported that the antioxidant properties of flavonoids are effective mainly via the scavenging of superoxide anion. MEBR was found to possess
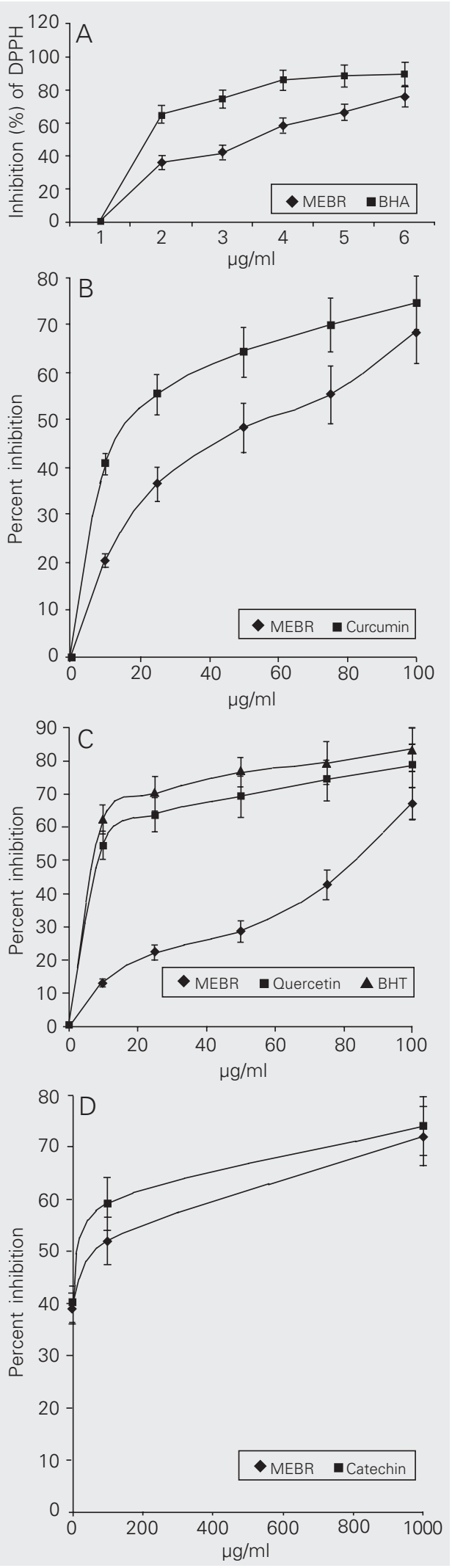

Figure 3. A, Free radical scavenging activity of a methanol extract of Bauhinia racemosa (MEBR, diamonds) and butylated hydroxy anisole (BHA, squares) by 1,1-diphenyl-2-picryl-hydrazol radicals. $B$, Inhibition of nitric oxide radicals by MEBR (diamonds) and curcumin (squares). C, Superoxide anion scavenging activity of MEBR (diamonds) and the same doses of quercetin (squares) and butylated hydroxy toluene (BHT, triangles). $D$, Hydroxyl radical scavenging activity of MEBR (diamonds) and catechin (squares) on deoxyribose damage. Data are reported as the means \pm SD for three measurements. $P<0.05$ compared to control $(\%$ inhibition by control = $0 \%$; ANOVA followed by the Student $t$-test). 
good scavenging activity on superoxide anions at all concentrations tested. MEBR at concentrations of 10 to $100 \mu \mathrm{g} / \mathrm{ml}$ inhibited the production of superoxide anion radicals by $13.05-67.02 \%$, showing strong superoxide radical scavenging activity. The results are given in Figure 3C. The $\mathrm{IC}_{50}$ value of MEBR on superoxide radical scavenging activity was found to be $109.17 \mu \mathrm{g} / \mathrm{ml}$, whereas the $\mathrm{IC}_{50}$ value of BHT and quercetin was 22.77 and $31.58 \mu \mathrm{g} / \mathrm{ml}$, respectively. The results were statistically significant $(\mathrm{P}<$ $0.05)$.

\section{Hydroxyl radical scavenging activity}

Hydroxyl radicals are the major active oxygen species causing lipid oxidation and enormous biological damage (33). FerricEDTA was incubated with $\mathrm{H}_{2} \mathrm{O}_{2}$ and ascorbic acid at $\mathrm{pH}$ 7.4. Hydroxyl radicals were formed in free solution and were detected by their ability to degrade 2-deoxy-2-ribose into fragments that formed a pink chromogen upon heating with TBA at low pH $(34,35)$.
When MEBR and the reference compound catechin were added to the reaction mixture they removed hydroxyl radicals from the sugar and prevented their degradation. The results are shown in Figure 3D. The MEBR was capable of reducing DNA damage at all concentrations. Catechin used as a standard was highly effective in inhibiting the oxidative DNA damage. The $\mathrm{IC}_{50}$ value of MEBR in the hydroxyl radical scavenging assay was $1789.13 \mu \mathrm{g} / \mathrm{ml}$, a statistically significant result $(\mathrm{P}<0.05)$.

\section{Amount of total phenolic compounds}

Phenols are very important plant constituents because of their scavenging ability due to their hydroxyl groups (36). In the MEBR (1 mg) $64.7 \mu \mathrm{g}$ pyrocatechol equivalents of phenols were detected. The phenolic compounds may contribute directly to the antioxidative action (37). The result indicates a strong association between antioxidative activities and phenolic compounds $\left(\mathrm{r}^{2}\right.$ $=0.9983)$, suggesting that phenolic com-

Table 1. Antimicrobial activity of the methanol extract of Bauhinia racemosa stem bark, ofloxacin and miconazole nitrate on selected bacterial and fungal strains.

Microorganism

Diameter of inhibition zone $(\mathrm{mm})$

\begin{tabular}{|c|c|c|c|c|c|}
\hline \multicolumn{4}{|c|}{ MEBR ( $\mu \mathrm{g} / \mathrm{ml}$ per disc) } & \multicolumn{2}{|c|}{ Standards } \\
\hline 25 & 50 & 100 & 200 & $\begin{array}{c}\text { Ofloxacin } \\
(5 \mu \mathrm{g} / \mathrm{ml} \mathrm{per} \mathrm{disc)}\end{array}$ & $\begin{array}{c}\text { Miconazole } \\
\text { (40 } \mathrm{\mu g} / \mathrm{ml} \text { per disc) }\end{array}$ \\
\hline
\end{tabular}

Pseudomonas aeruginosa

Escherichia coli

Salmonella typhi

Shigella dysenteriae

Vibrio cholerae

Staphylococcus aureus

Streptococcus pneumoniae

Micrococcus luteus

Staphylococcus epidermidis

Candida albicans

Aspergillus niger

Aspergillus flavus

Alternaria solani

$\begin{array}{rrrrr}8 & 10 & 14 & 17 & 22 \\ - & 9 & 12 & 15 & 26 \\ 10 & 13 & 16 & 19 & 24 \\ 8 & 10 & 12 & 15 & 2 \\ - & 8 & 10 & 14 & 20 \\ - & 8 & 10 & 13 & 14 \\ - & 8 & 10 & 14 & 22 \\ 8 & 9 & 11 & 14 & 19 \\ - & 8 & 10 & 13 & 23 \\ - & 8 & 11 & 15 & - \\ - & 7 & 8 & 12 & - \\ - & - & 7 & 11 & - \\ - & 8 & 11 & 15 & \end{array}$

22
26
24
21
20
14
22
19
23
-
-
-
-

20

4

23

21

19

$\begin{array}{ll}- & 19 \\ - & 22\end{array}$

Data are reported as the means of three tests each carried out in triplicate after $24-72 \mathrm{~h}$ of inhibition at $37^{\circ} \mathrm{C}$. MEBR = methanol extract of Bauhinia racemosa stem bark; $(-)=$ inactive. 
pounds are probably responsible for the antioxidative activities of $B$. racemosa. Phenolic compounds are also effective hydrogen donors, which makes them good antioxidants (38). Similarly Shahidi and Naczk (39) reported that naturally occurring phenolic compounds exhibit antioxidative activity. Thus, the therapeutic properties of $B$. racemosa may be possibly attributed to the phenolic compounds present.

\section{Antimicrobial activity}

Disc diffusion methods are used extensively to investigate the antibacterial activity of natural substances and plant extracts. These assays are based on the use of discs as reservoirs containing solutions of the substances to be examined. In the case of solutions with a low activity, however, a large concentration or volume is needed. Because of the limited capacity of discs, holes or cylinders are preferably used (40).

Most of the bacterial species and the fungal species were inhibited by the plant extract, as shown in Table 1. In this study, nine different bacterial and four fungal spe- cies were used to screen the possible antimicrobial activities of the methanol extract of B. racemosa stem bark. The MEBR showed a broad spectrum of activity against all the bacterial strains at the tested concentration of $25-200 \mu \mathrm{g} / \mathrm{disc}$, as summarized in Table 1. The MEBR showed antimicrobial activity against all tested bacterial and fungal stains at the concentration of $50 \mu \mathrm{g} / \mathrm{disc}$. Ofloxacin $(5 \mu \mathrm{g} /$ disc $)$ and miconazole nitrate $(40 \mu \mathrm{g} /$ disc) were used as positive controls for bacteria and fungi.

On the basis of the results obtained in the present study, we conclude that the methanol extract of $B$. racemosa has significant amounts of antioxidant and antimicrobial activity. Further studies are needed to isolate the exact active component, which are responsible for the antioxidant and antimicrobial activities.

\section{Acknowledgments}

R. Sambath Kumar is grateful to AICTE, New Delhi, India, for providing financial support for this study.

\section{References}

1. Gulcin I, Buyukokuroglu ME, Oktay M \& Kufrevioglu OI (2002). On the in vitro antioxidant properties of melatonin. Journal of Pineal Research, 33: 167-171.

2. Halliwell B \& Gutteridge JM (1999). Free Radicals in Biology and Medicine. Oxford University Press, Oxford, UK.

3. Yildirim A, Mavi A, Oktay M, Kara AA, Algur OF \& Bilaloglu V (2000). Comparison of antioxidant and antimicrobial activities of tilia (Tilia argenta Desf Ex DC), sage (Salvia triloba L.) and black tea (Camellia sinensis) extracts. Journal of Agricultural and Food Chemisty, 48: 5030-5034.

4. Lai LS, Chou ST \& Chao WW (2001). Studies on the antioxidative activities of Hsian-tsao (Mesona procumbens Hemsl) leaf gum. Journal of Agricultural and Food Chemistry, 49: 963-968.

5. Buyukokuroglu ME, Gulcin I, Oktay M \& Kufrevioglu OI (2001). In vitro antioxidant properties of dantrolene sodium. Pharmacological Research, 44: 491-494.

6. Davies KJA (1994). Oxidative stress: the paradox of aerobic life. Biochemical Society Symposium, 61: 1-34.

7. Halliwell B \& Gutteridge JM (1989). Free Radicals in Biology and Medicine. Clarendon Press, Oxford, UK.
8. Robinson EE, Maxwell SRJ \& Thorpe GHG (1997). An investigation of antioxidant activity of black tea using enhanced chemiluminescence. Free Radical Research, 26: 291-302.

9. Kirtikar KR \& Basu BD (1975). Indian Medicinal Plants. Vol. 2. 2nd edn. Bishen Singh Mahendra Pal Singh, Dehradun, India, 894-895.

10. Prakash A \& Khosa RL (1976). Chemical studies on Bauhini racemosa. Current Science, 45: 705-707.

11. El-Hossary GA, Selim MA, Sayed AE \& Khaleel AE (2000). Study of the flavonoid content of Bassia muricata and Bauhinia racemosa. Bulletin of the Faculty of Pharmacy, Cairo University, 38: 93-97.

12. Anjaneyulu ASR, Reddy AVR, Reddy DSK, Ward RS, Adhikesavalu D \& Cameron TS (1984). A new dibenzo $(2,3-6,7)$ oxepin derivative from Bauhinia racemosa. Tetrahedron, 40: 4245-4252.

13. El-Khatiba AS \& Khaleel AE (1995). Evaluation of some pharmacological properties of different extracts of Bauhinia racemosa leaf and Bassia muricata whole plant. Bulletin of the Faculty of Pharmacy, Cairo University, 33: 59-65.

14. Ali MS, Azhar I, Amtul Z, Ahmad VU \& Usmanghani K (1995). Antimicrobial screening of some Caesalpiniaceae. Fitoterapia, 70 : 299-304. 
15. Akhtar AH \& Ahmad KU (1995). Anti-ulcerogenic evaluation of the methanol extract of some indigenous medicinal plants of Pakistan in aspirin ulcerated rats. Journal of Ethnopharmacology, 46: 1-6.

16. Dhar ML, Dhar MM, Dhawan BN, Mehrotra BN \& Roy C (1968). Screening of Indian plants for biological activity. Indian Journal of Experimental Biology, 6: 232-247.

17. Gupta M, Mazumder UK, Siva Kumar T, Sambath Kumar R \& Gomathi P (2004). Antioxidant and hepatoprotective effects of Bauhinia racemosa against paracetamol and carbon tetra chloride induced liver damage in rats. Iranian Journal of Pharmacology and Therapeutics, 3: 12-20.

18. Gupta M, Mazumder UK, Sambath Kumar R \& Siva Kumar T (2004). Antitumor effect of Bauhinia racemosa against Ehrlich ascites carcinoma with reference to lipid peroxidation and antioxidant system in Swiss albino mice. Acta Pharmacologica Sinica, 25: 1070-1076.

19. Mistuda H, Yuasumoto K \& Iwami K (1996). Antioxidation action of indole compounds during the autoxidation of linoleic acid. Nihon Eiyo Shokuryo Gakkai-Shi, 19: 210-214.

20. Yen GH \& Chen HY (1995). Antioxidant activity of various tea extracts in relation to their antimutagenicity. Journal of Agricultural and Food Chemistry, 43: 27-32.

21. Oyaizu M (1986). Studies on product of browning reaction prepared from glucose amine. Japanese Journal of Nutrition, 44: 307-315.

22. Blois MS (1958). Antioxidant determinations by the use of a stable free radical. Nature, 29: 1199-1200.

23. Green LC, Wagner DA, Glogowski J, Skipper PL, Wishnok JK \& Tannenbaum SR (1982). Analysis of nitrate, nitrite and $15 \mathrm{~N}$ nitrate in biological fluids. Analytical Biochemistry, 126: 131-138.

24. Nishimiki M, Rao NA, Appaji N \& Yagi K (1972). The occurrence of superoxide anion in the reaction of reduced phenazine methosulfate and molecular oxygen. Biochemical and Biophysical Research Communications, 46: 849-854.

25. Kunchandy E \& Rao MNA (1990). Oxygen radical scavenching activity of curcumin. International Journal of Pharmacognosy, 58: 237240.

26. Slinkard K \& Singleton VL (1977). Total phenol analyses; automation and comparison with manual methods. American Journal of Enology and Viticulture, 28: 49-55.

27. Mackeen MM, Ali AM, El-Sharkawy SH, Manap MY, Salleh KM, Lajis NH \& Kawazu K (1997). Antimicrobial and cytotoxic properties of some Malaysian traditional vegetables. International Journal of Pharmacognosy, 35: 237-243.

28. Wang C \& Wixon R (1999). Phytochemicals in soybeans: their potential health benefits. INFORM, 10: 315-321

29. Tanaka M, Kuie CW, Nagashima Y \& Taguchi T (1988). Application of antioxidative Maillard reaction products from histidine and glucose to saline products. Nippon Suisan Gakkai-Shi, 54: 1409-1414.

30. Okuda T, Kimura Y, Yoshida T, Hatano T, Okuda H \& Arichi S (1983). Studies on the activities of tannins and related compounds from medicinal plants and drugs. I. Inhibitory effects on lipid peroxidation on mitochondria and microsomes of liver. Chemical and Pharmaceutical Bulletin, 31: 1625-1631.

31. Mier S, Kaner J, Akiri B \& Hadas SP (1995). Determination and involvement of aqueous reducing compounds in oxidative defense systems of various senescing leaves. Journal of Agricultural and Food Chemistry, 43: 1813-1817.

32. Robak J \& Gryglewski IR (1988). Flavonoids are scavengers of superoxide anions. Biochemical Pharmacology, 37: 837-841.

33. Aurand LW, Boonme NH \& Gidding GG (1977). Superoxide and singlet oxygen in milk lipid peroxidation. Journal of Dairy Science, 60: 363-369.

34. Halliwell B, Gutteridge JMC \& Aruoma OI (1987). The deoxyribose method: a simple 'test tube' assay for determination of rate constants for reaction of hydroxyl radicals. Analytical Biochemistry 165: $215-219$

35. Aruoma Ol, Laughton MJ \& Halliwell B (1989). Carnosine, homocarnosine and anserine: could they act as antioxidants in vivo? Biochemical Journal, 264: 863-869.

36. Diplock AT (1997). Will the 'good fairies' please prove to us that vitamin $\mathrm{E}$ lessens human degenerative disease? Free Radical Research, 27: 511-532.

37. Hatano T, Edamatsu R, Hiramatsu M, Mori A, Fujita $Y$ \& Yasuhara D (1989). Effects of interaction of tannins with co-existing substances. $\mathrm{VI}$. Effects of tannins and related polyphenols on superoxide anion radical and on DPPH radical. Chemical and Pharmaceutical Bulletin, 37: 2016-2021.

38. Rice-Evans CA, Miller NJ, Bolwell PG, Bramley PM \& Pridham JB (1995). The relative antioxidant activity of plant derived polyphenolic flavonoids. Free Radical Research, 22: 375-383.

39. Shahidi F \& Naczk M (1995). Method of Analysis and Quantification of Phenolic Compounds. Technomic Publishing Company, Lanchester, PA, USA, 287-293.

40. Bartner A, Pfeiffer KP \& Batner H (1994). Applicability of disc diffusion methods required by the pharmacopoeias for testing antibacterial activity of natural compounds. Pharmazie, 49: 512-516. 